\title{
Validation and standardization of Kveim test suspensions prepared from two human sarcoid spleens
}

\author{
D. N. MITCHELL, IAN SUTHERLAND, C. M. PATRICIA BRADSTREET, AND \\ MABEL W. DIGHERO \\ MRC Tuberculosis and Chest Diseases Unit, Brompton Hospital, London SW3, MRC Statistical Research \\ and Services Unit, University College Hospital Medical School, London WC1, and the Standards Laboratory, \\ Central Public Health Laboratory, London NW9
}

SYNOPSIS Single lots of a Chase-Siltzbach type I Kveim test material from each of two sarcoid spleens and designated lot 5 of spleen $\mathrm{K} 12$ and lot 1 of spleen $\mathrm{K} 13$ have been validated alongside a single lot (lot 10) of a 'standard' suspension provided by Dr L. E. Siltzbach and prepared identically from the spleen of patient $\mathbf{J}$ (spleen $\mathbf{J}$ ) in New York. Additionally, a half-dilution of lot 5, K12, was included in this comparison. The reactivity of each suspension was assessed among patients with active and inactive sarcoidosis. The selectivity of each suspension for sarcoidosis was assessed similarly by comparison with results in patients with active and quiescent pulmonary parenchymal tuberculosis and in healthy subjects. All patients were closely matched and two Kveim tests were made in each subject according to a prearranged statistical design. The reactivity of the $\mathrm{K} 12, \mathrm{~K} 12 \frac{1}{2}$ dilution, and K13 suspensions among patients with active and inactive sarcoidosis was closely similar to that with the 'standard' S10 suspension and in accordance with the expected proportions of reactions in patients at different stages of sarcoidosis. The K12, K13, and 'standard' S10 suspensions yielded a negligible proportion of positive reactions among patients with active and quiescent pulmonary tuberculosis and among healthy subjects: thus, as judged by these tests each suspension showed a high degree of selectivity for sarcoidosis.

The results of this validation study are discussed in relation to the results of other studies in which lots 5 and 14 of $\mathrm{K} 12$ and early and late batches of a suspension prepared from another sarcoid spleen at the Commonwealth Serum Laboratories designated CSL and provided by Dr T. H. Hurley in Melbourne were employed. Using lot 5 of $\mathrm{K} 12$ positive reactions were found in an appreciable proportion of patients with Crohn's disease, ulcerative colitis, and tuberculous lymphadenitis. A closely similar rate of positive reactions was encountered among patients with Crohn's disease following tests with batch 0025 of CSL suspension and with another lot (lot 14) derived from spleen $\mathrm{K} 12$. A close concordance of results was obtained with lot 5 (K12) and with batch 0042 CSL among patients with ulcerative colitis, but at a lower rate of reactivity.

We conclude that positive reactions also occur in some diseases other than sarcoidosis and consider that the difficulties in determining the criteria for an acceptable test suspension become increasingly apparent as additional Kveim tests are made with one particular lot and with seqential lots of material from a 'validated' tissue source.

The human sarcoid spleen represents the best source of Kveim test material. Although satisfactory test suspensions can also be prepared from other tissues affected by sarcoidosis, a spleen, once it has been validated, will by virtue of its size ensure an ample Received for publication 15 September 1975 supply of sequential lots of potentially acceptable test materials for general use over a prolonged period. Unfortunately, the histological appearances of a sarcoid spleen give no guidance to either the reactivity or the selectivity of suspensions prepared from it; these can be determined only by biological assay 
in man. Kveim tests in patients with definite clinical sarcoidosis will determine the reactivity of the suspension: comparison with identical tests among patients with other granulomatous and nongranulomatous diseases (particularly tuberculosis) and among healthy subjects will determine its selectivity for sarcoidosis.

\section{Objectives}

The objectives of the present study were to assess the macroscopic and microscopic response at the Kveim test site four to six weeks after the intracutaneous injection of Kveim test suspensions prepared from two human sarcoid spleens, in comparison with the reactions to a standard validated suspension. Tests were made in patients with active sarcoidosis, inactive sarcoidosis, active and quiescent pulmonary parenchymal tuberculosis, and in healthy subjects.

\section{MATCHING OF SUBJECTS}

Each patient with clinically active sarcoidosis was given two simultaneous Kveim tests according to a prearranged statistical design, and the same pair of simultaneous tests was given at the same sites in one subject in each of the following categories:

1 a patient with definite but inactive sarcoidosis matched for:
(a) sex,
(b) age on initial diagnosis (to within 5 years),
(c) form of disease present at the time of the first abnormal chest radiograph,
(d) tuberculin status at the time of the first abnormal chest radiograph (when possible);

2 a patient with confirmed active pulmonary tuberculosis matched for:
(a) sex,
(b) age on initial diagnosis (to within 5 years);

3 a patient with confirmed quiescent pulmonary parenchymal tuberculosis matched for:

(a) sex,

(b) age on initial diagnosis (to within 5 years);

4 an apparently healthy subject matched for:

(a) sex,

(b) age of the patient with active sarcoidosis on initial diagnosis (to within 5 years).

\section{Material and Methods}

TEST SPLEENS

Spleen $K 12$

A spleen was obtained at splenectomy for hypersplenism from a woman aged 35 years with hilar lymphadenopathy and widespread pulmonary infiltration attributed to sarcoidosis. A scalene node biopsy had shown non-caseating giant-cell granu-Ō lomas and microscopically the Kveim test was. weakly positive.

\section{Spleen $K 13$}

A sarcoid spleen was obtained at necropsy from a $\frac{\overline{\bar{p}}}{\overline{\frac{\sigma}{5}}}$ woman aged 74 years whose chest radiograph $\widetilde{\Omega}_{\Omega}$ showed hilar lymphadenopathy and pulmonaryo infiltration with fibrosis attributed to sarcoidosis. A scalene node biopsy had shown non-caseating. giant-cell granulomas but the Kveim test was $\vec{\omega}$ microscopically negative.

\section{STANDARD SUSPENSION}

This suspension (designated S10) was supplied by Dr L. E. Siltzbach from lot 10 of a validated spleeni (spleen J). It contained $450 \mu \mathrm{g}$ alcohol-precipitable $\Theta_{0}$ material per test dose.

\section{TEST SUSPENSIONS}

The three test suspensions were all of type 1 (Chase- $\frac{0}{2}$ Siltzbach) prepared according to the technique of $⿱ 乛$ Chase (1961) in a manner identical with that of S10. $\vec{\varphi}$ They were:

K12 undiluted-This lot (lot 5) contained $1250 \mu \mathrm{g}$ per test dose.

$\mathrm{K} 12 \frac{1}{2}$ dilution-This was a half dilution of $\mathrm{K} 12 \frac{3}{3}$ (lot 5). K13 undiluted-This lot (lot 1) contained $880 \mu \stackrel{\text { ga }}{\text { per test dose. }}$
$\Rightarrow$

Each suspension was dispensed in identical rubber- $\overrightarrow{\overrightarrow{0}}$ capped glass vials $(2 \mathrm{ml})$ identified only by a code 3 number to conceal the nature of the suspension as far as possible from the tester and the readers.

\section{THE KVEIM TEST}

The dose of each Kveim reagent was that contained in $0.15 \mathrm{ml}$ of the test suspension, drawn into a $1 \mathrm{mlo}$ tuberculin-type disposable syringe after shaking the vial to ensure a uniform suspension. The injectionso were made through a 26 gauge needle, through which each particulate suspension was found too pass freely.

\section{The Kveim test sites}

The two tests on each patient were made intracutaneously on the ulnar aspect of the forearm. The two sites were chosen at random from four possible standard test sites, two on each forearm. All the tests were made by one person (DNM).

\section{Method of locating test sites}

The location of each Kveim test was identified by a single tattoo speck of autoclaved Gunther-Wagnerबि Pelikan Ink just breaking the epidermis within the medial edge of each injected weal. 


\section{Reading of the Kveim test sites}

Each test site was examined carefully immediately before biopsy, that is, at four to six weeks following injection. The maximum diameter of any papule at each test site was measured with calipers and recorded in millimetres (by DNM).

\section{Biopsy of Kveim test site}

A full thickness skin biopsy at each of the two test sites was made in each patient four to six weeks after injection. All the biopsies were made by one person (DNM). The skin at each test site was cleaned with $70 \%$ alcohol, and $2 \%$ xylocaine with adrenaline was then injected into the skin at the test site. A Hayes Martin drill biopsy punch with a $4 \mathrm{~mm}$ knife was used to excise the full thickness of skin at the injection site, the knife removing a core of skin extending down to the subcutaneous tissue. A 'butterfly' band-aid was then used to appose the edges of the wound and avoid the need for sutures. Each biopsy specimen was transferred to $10 \%$ formalin and prepared histologically. Serial sections were prepared, and every twentieth was mounted and stained with haematoxylin and eosin.

\section{Microscopic assessment of Kveim test biopsies}

The sections from each Kveim test biopsy were read independently, according to the criteria in the Appendix, by two observers (JGS and DNM), who were unaware of the nature of the suspension or the clinical status of the subjects.

\section{TUBERCULIN TESTS}

To assist the matching process, a tuberculin test was made where possible with $0 \cdot 1 \mathrm{ml}$ of $1 / 3000$ Old Tuberculin ( $3 \mathrm{TU})$ in all patients with clinically active or inactive sarcoidosis. The test site was distinct from those for the Kveim tests. The tuberculin test was given at the same time as the two Kveim tests and was read at three days. The maximum diameter of induration was recorded in millimetres. A tuberculin test with 100 TU was made at a site distinct from those of previous tests in all patients in whom the reaction to $3 \mathrm{TU}$ was less than $5 \mathrm{~mm}$. These tests were also read at three days, and the maximum diameter of any induration was recorded in millimetres.

\section{DESIGN OF STUDY}

The study was made on 18 sets of five subjects, each set consisting of one patient with active sarcoidosis, one with inactive sarcoidosis, one with active and one with quiescent pulmonary tuberculosis, and one healthy subject, matched according to the criteria stated above. There are six different combinations of the four tests taken in pairs, and each combination was tested on three patients with active sarcoidosis and on the subjects matched with them. Thus each of the four suspensions was tested on nine patients with active sarcoidosis (and their matches).

\section{Results}

MICROSCOPIC READINGS OF KVEIM TEST RESULTS

Because of the involvement of the other reader (DNM) in the test and biopsy procedures, the microscopic results presented here are based on the readings of one reader only (JGS). The two sets of readings were, however, closely similar. There was complete agreement of reading in $87 \%$ of the total of 180 biopsies, and in only four of the 24 disagreements was there a major difference (that is, one reading 'positive', the other 'negative'), the remainder all involving the 'equivocal' category.

\section{Reactivity (table I)}

Among the 18 patients with active sarcoidosis 12 $(67 \%)$ had at least one positive biopsy (the companion biosy was positive in 7 , equivocal in 2 , and negative in 3$)$. Among the 18 patients with inactive sarcoidosis four $(22 \%)$ had at least one positive biopsy (the companion biopsy was positive in 1 and equivocal in 3 ); in addition, one patient had an equivocal reading for both biopsies. A comparison of the reactions in the matched pairs of patients with active and inactive sarcoidosis, scoring $\frac{1}{2}$ for each positive and $\frac{1}{4}$ for each equivocal reading, shows a significantly greater reactivity of the Kveim test in the patients with active sarcoidosis than in those with inactive sarcoidosis $(P<0.05$, Wilcoxon rank test).

\section{Selectivity (table I)}

Among the 36 patients with pulmonary tuberculosis (18 active, 18 quiescent) none had a positive biopsy. Among the 18 healthy subjects one had a positive biopsy (the companion being negative).

\section{Reactivity of the four test suspensions}

Table II summarizes the readings in each group of patients according to the test suspension. There are no obvious differences in reactivity between the S10, $\mathrm{K} 12$, and $\mathrm{K} 12 \frac{1}{2}$ suspensions in either active or inactive sarcoidosis, but the figures in the table suggest that suspension K13 may have been rather less reactive than the other three. However, a detailed analysis of the differences between the reactions to the pair of suspensions used on each patient does not show any significant differences between the four suspensions. 


\begin{tabular}{|c|c|c|c|c|c|c|c|c|}
\hline \multirow[t]{2}{*}{ Subjects } & \multirow[t]{2}{*}{ Total Patients } & \multicolumn{7}{|c|}{ Readings of the Two Biopsies } \\
\hline & & $\begin{array}{l}\text { Positive } \\
\text { Positive }\end{array}$ & $\begin{array}{l}\text { Positive } \\
\text { Equivocal }\end{array}$ & $\begin{array}{l}\text { Positive } \\
\text { Negative }\end{array}$ & $\begin{array}{l}\text { Equivocal } \\
\text { Equivocal }\end{array}$ & $\begin{array}{l}\text { Equivocal } \\
\text { Negative }\end{array}$ & $\begin{array}{l}\text { Negative } \\
\text { Negative }\end{array}$ & $\begin{array}{l}\text { Patients with a } \\
\text { Positive Result (\%) }\end{array}$ \\
\hline Active sarcoidosis & 18 & 7 & 2 & 3 & 0 & 0 & 6 & 67 \\
\hline Inactive sarcoidosis & 18 & 1 & 3 & 0 & 1 & 1 & 12 & 22 \\
\hline Active pulmonary tuberculosis & 18 & 0 & 0 & 0 & 0 & 1 & 17 & 0 \\
\hline \multirow{2}{*}{\multicolumn{9}{|c|}{$\begin{array}{l}\text { Quiescent pulmonary } \\
\text { tuberculosis }\end{array}$}} \\
\hline & 18 & 0 & 0 & 0 & 0 & 2 & 16 & 0 \\
\hline Healthy & 18 & $\mathbf{0}$ & 0 & 1 & 0 & 1 & 16 & 6 \\
\hline
\end{tabular}

Table I Results of microscopic readings of the two Kveim test biopsies in each patient

\begin{tabular}{|c|c|c|c|c|c|}
\hline \multirow[t]{2}{*}{ Subjects } & \multirow[t]{2}{*}{ Suspension } & \multicolumn{4}{|c|}{ Biopsies } \\
\hline & & Total & Positive & Equivocal & Negative \\
\hline \multirow[t]{4}{*}{ Active sarcoidosis } & S10 & 9 & 5 & 1 & 3 \\
\hline & $\mathrm{K} 12$ & 9 & 6 & 0 & 3 \\
\hline & $\mathrm{K} 12 \frac{1}{2}$ & 9 & 5 & 0 & 4 \\
\hline & K 13 & 9 & 3 & 1 & 5 \\
\hline \multicolumn{2}{|c|}{ Total } & 36 & 19 & 2 & 15 \\
\hline \multirow{4}{*}{ Inactive sarcoidosis } & $\mathrm{S} 10$ & 9 & 2 & 4 & 3 \\
\hline & $\mathrm{K} 12$ & 9 & 1 & 2 & 6 \\
\hline & $\mathrm{K} 12 \frac{1}{2}$ & 9 & 2. & 0 & 7 \\
\hline & $\mathrm{K} 13$ & 9 & 0 & 0 & 9 \\
\hline Total & & 36 & 5 & 6 & 25 \\
\hline \multirow{4}{*}{$\begin{array}{l}\text { Pulmonary tuberculosis (active and } \\
\text { quiescent) }\end{array}$} & $\mathrm{S} 10$ & 18 & 0 & $2^{1}$ & 16 \\
\hline & $\mathrm{K} 12$ & 18 & 0 & $\overline{1}$ & 17 \\
\hline & K12! & 18 & 0 & 0 & 18 \\
\hline & $\mathrm{K} 13$ & 18 & 0 & 0 & 18 \\
\hline Total & & 72 & 0 & 3 & 69 \\
\hline \multirow[t]{5}{*}{ Healthy } & S10 & 9 & 0 & 0 & 9 \\
\hline & $\mathrm{K} 12$ & 9 & 1 & 0 & 8 \\
\hline & $\mathrm{K} 12 \frac{1}{2}$ & 9 & 0 & 0 & 9 \\
\hline & $\mathrm{K} 13$ & 9 & 0 & 1 & 8 \\
\hline & & 36 & 1 & 1 & 34 \\
\hline
\end{tabular}

Table II Results of microscopic readings of each Kveim test biopsy according to test suspension

${ }^{1}$ Including the one equivocal result in a patient with active pulmonary tuberculosis

READINGS OF PAPULE SIZE

Table III summarizes the diameters of the Kveim test papules in each group of subjects according to the test suspension. The mean papule sizes were significantly larger in patients with active sarcoidosis than in those with inactive sarcoidosis $(3.4 \mathrm{~mm}$ compared with $1.8 \mathrm{~mm}, \mathrm{P}<0.001)$. In all, papules were found in 41 of the 72 test sites in patients with pulmonary tuberculosis, and in only one of the 36 test sites in healthy subjects.

There are no obvious differences in mean papule size between the four suspensions within each group of patients.

PAPULE SIZE IN RELATION TO THE MICROSCOPIC READING

Table IV shows that there is a close correlation between the papule size and the microscopic reading $(\mathrm{P}<0.001)$. The mean papule diameters were 3.8 , $2 \cdot 4$, and $1.1 \mathrm{~mm}$ for those positive, equivocal, and negative on biopsy, respectively.
It is of interest that the mean papule sizes for the microscopically negative biopsies (as for all biopsies $\bar{B}$. were greater in patients with active sarcoidosis thari in those with inactive sarcoidosis or pulmonary tuberculosis, and that these were in turn greater than in healthy subjects (table V). This indicates that the macroscopic as well as the microscopico reading is relevant to a full interpretation of the result of the Kveim test.

TUBERCULIN TESTS IN THE SARCOIDOSISN PATIENTS

Of the 18 patients with active sarcoidosis (table VI) six were positive to $3 \mathrm{TU}$, five were positive to 100 TU only, and seven were negative to $3 \mathrm{TU}$ and $100 \mathrm{P}$ TU. Of the 18 patients whose sarcoidosis was inactive at the time of testing, four were positive to $3 \mathrm{TU}$, three were positive to $100 \mathrm{TU}$ only, and $11 \mathrm{D}$ were negative to 3 and 100 TU. Tuberculin tests were not made in connection with this study in the patients with tuberculosis or in the healthy subjects. 


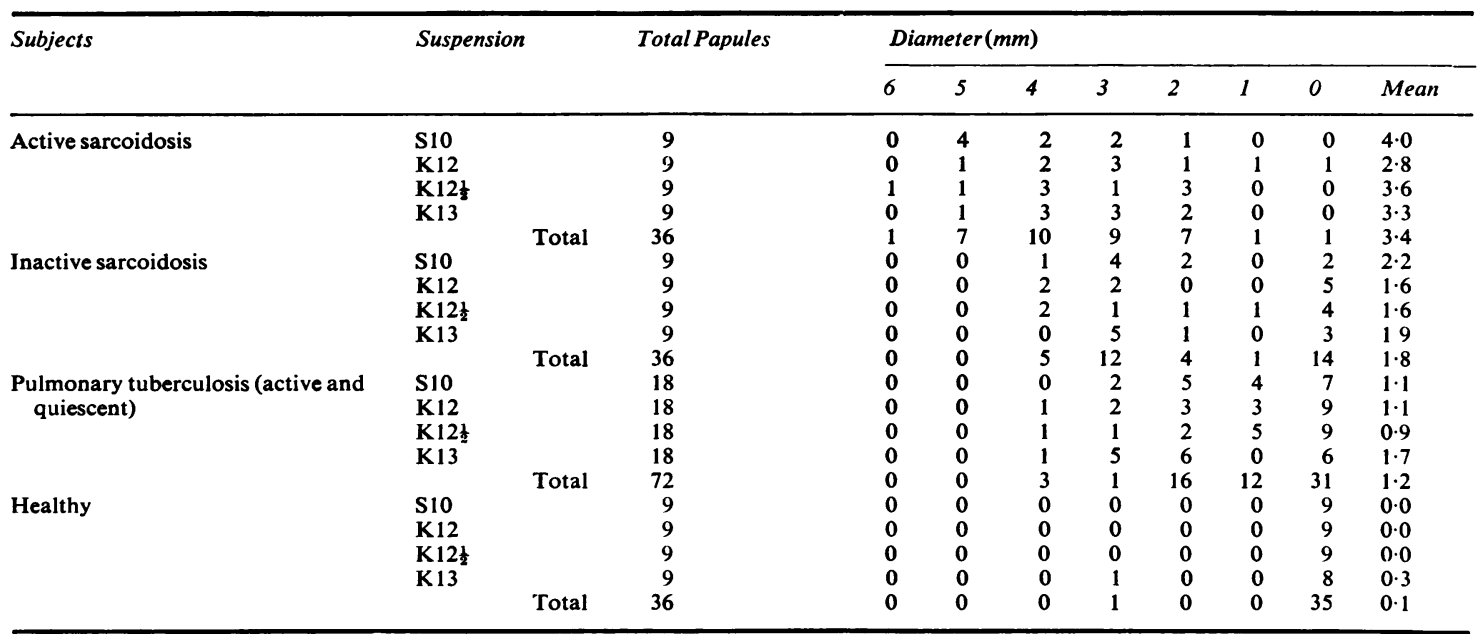

Table III Diameter of Kveim test papules according to test suspension

\begin{tabular}{|c|c|c|c|c|c|c|c|c|c|}
\hline \multirow[t]{2}{*}{ Microscopic Reading } & \multirow[t]{2}{*}{ Total Papules } & \multicolumn{8}{|c|}{ Diameter (mm) } \\
\hline & & 6 & 5 & 4 & 3 & 2 & 1 & 0 & Mean \\
\hline $\begin{array}{l}\text { Positive } \\
\text { Equivocal } \\
\text { Negative }\end{array}$ & $\begin{array}{r}25 \\
12 \\
143\end{array}$ & $\begin{array}{l}1 \\
\mathbf{0} \\
\mathbf{0}\end{array}$ & $\begin{array}{l}\mathbf{7} \\
\mathbf{0} \\
\mathbf{0}\end{array}$ & $\begin{array}{l}1 \\
3 \\
5\end{array}$ & $\begin{array}{r}5 \\
4 \\
23\end{array}$ & $\begin{array}{r}0 \\
2 \\
25\end{array}$ & $\begin{array}{r}0 \\
0 \\
14\end{array}$ & $\begin{array}{r}2 \\
3 \\
76\end{array}$ & $\begin{array}{l}3 \cdot 8 \\
2 \cdot 4 \\
1 \cdot 1\end{array}$ \\
\hline
\end{tabular}

Table IV Diameter of Kveim test papules according to microscopic readings

\begin{tabular}{|c|c|c|c|c|c|c|c|c|}
\hline \multirow[t]{3}{*}{ Subjects } & \multicolumn{6}{|c|}{ Microscopic Reading } & \multicolumn{2}{|c|}{ All Subjects } \\
\hline & \multicolumn{2}{|l|}{ Positive } & \multicolumn{2}{|c|}{ Equivocal } & \multicolumn{2}{|l|}{ Negative } & \multirow[b]{2}{*}{$\begin{array}{l}\text { No. } \\
\text { Papules }\end{array}$} & \multirow[b]{2}{*}{$\begin{array}{l}\text { Mean } \\
\text { Diam. }\end{array}$} \\
\hline & $\begin{array}{l}\text { No. } \\
\text { Papules }\end{array}$ & $\begin{array}{l}\text { Mean } \\
\text { Diam. }\end{array}$ & $\begin{array}{l}\text { No. } \\
\text { Papules }\end{array}$ & $\begin{array}{l}\text { Mean } \\
\text { Diam. }\end{array}$ & $\begin{array}{l}\text { No. } \\
\text { Papules }\end{array}$ & $\begin{array}{l}\text { Mean } \\
\text { Diam. }\end{array}$ & & \\
\hline Active sarcoidosis & 19 & $4 \cdot 3$ & 2 & $4 \cdot 0$ & 15 & $2 \cdot 2$ & 36 & $3 \cdot 4$ \\
\hline Inactive sarcoidosis & 5 & $2 \cdot 8$ & 6 & $2 \cdot 5$ & 25 & $1 \cdot \overline{5}$ & 36 & $1 \cdot 8$ \\
\hline $\begin{array}{l}\text { Pulmonary tuberculosis (active and } \\
\text { quiescent) }\end{array}$ & 0 & - & 3 & $1 \cdot 7$ & 69 & $1 \cdot 3$ & 72 & $1 \cdot 2$ \\
\hline Healthy & 1 & 0.0 & 1 & 0.0 & 34 & $0 \cdot 1$ & 36 & $0 \cdot 1$ \\
\hline All & 25 & $3 \cdot 8$ & 12 & $2 \cdot 4$ & 143 & $1 \cdot 1$ & 180 & $1 \cdot 5$ \\
\hline
\end{tabular}

Table V Mean diameter of Kveim test papules according to microscopic readings in each group of patients

\begin{tabular}{|c|c|c|c|c|}
\hline \multirow[t]{2}{*}{ Subjects } & \multirow[t]{2}{*}{ Total tested } & \multicolumn{2}{|c|}{ Negative to $3 \mathrm{TU}$} & \multirow[b]{2}{*}{$\begin{array}{l}\text { Positive to } \\
3 T U\end{array}$} \\
\hline & & $\begin{array}{l}\text { Positive to } \\
100 T U\end{array}$ & $\begin{array}{l}\text { Negative to } \\
\text { loOTU }\end{array}$ & \\
\hline $\begin{array}{l}\text { Active sarcoidosis } \\
\text { Inactive sarcoidosis }\end{array}$ & $\begin{array}{r}18 \\
118\end{array}$ & $\begin{array}{l}5 \\
3\end{array}$ & $\begin{array}{r}7 \\
11\end{array}$ & $\begin{array}{l}6 \\
4\end{array}$ \\
\hline
\end{tabular}

Table VI Tuberculin sensitivity in the sarcoidosis patients

\section{Discussion}

The results obtained with the $\mathrm{K} 12$ suspension in this study show that this Kveim test material is reactive in sarcoidosis and is also highly selective for this disease. A positive Kveim reaction was obtained in 6 of 9 patients with active sarcoidosis. In patients with inactive sarcoidosis at the time of testing, 1 of 9 showed a positive Kveim test. The corresponding figures for the half-dilution of $\mathrm{K} 12$ were 5 of 9 and 2 of 9 . These findings are closely similar to those with the 'standard' S10 suspension 
in this study, namely 5 of 9 patients with active, and 2 of 9 patients with inactive sarcoidosis. Hirsch et al (1961) reported the results of a study in which a Kveim suspension, again a type I of Chase and Siltzbach similar to the 'standard' S10 suspension used in the present study, was likewise injected intracutaneously into persons with sarcoidosis and various other diseases. Again the test sites were removed by punch biopsy four to six weeks after injection, and sections of these biopsies were assessed by two observers who were unaware of the clinical diagnosis. A positive Kveim test was found in $75 \%$ of 71 patients with subacute active sarcoidosis and in $64 \%$ of 45 patients in whom active sarcoidosis was known to have been present for more than two years. The lower reactivity in subjects with inactive sarcoidosis appears to be related to the interval since onset of the disease (Siltzbach, 1961a, b).

With regard to the selectivity of the K12 suspension, one positive reaction was found among nine apparently healthy subjects and none among 18 patients with pulmonary tuberculosis. With the halfdilution, the figures were 0 of 9 and 0 of 18 . Similarly, Hirsch et al (1961) found positive Kveim reactions in less than $5 \%$ of 43 subjects with arrested tuberculosis or connective tissue disease, and among young schizophrenic men who had negative tuberculin tests.

The findings for the $\mathrm{K} 12$ suspension are similar to the more recent findings of the international Kveim test study reported by Siltzbach (1967) in which, of those with biopsy confirmed sarcoidosis of less than two years' duration, $62 \%$ gave a positive reaction following tests with his suspension. Among those with 'chronic' lesions, $38 \%$ responded, demonstrating again the waning of Kveim reactivity with the passage of time; only two $(1.2 \%)$ positive reactions were seen, both in patients with leprosy, of the 173 subjects tested in the control group.

The findings of a negative Kveim test among some patients with recent active sarcoidosis remains unexplained. None of the patients in the present study were receiving corticosteroids during the period of Kveim testing, which is known to depress the Kveim reaction (James and Thompson, 1955; Nelson, 1957; Siltzbach, 1961a, b).

The concentration of the Chase-Siltzbach suspensions used in this study varied widely. Thus, in tests with standard S10 material $450 \mu \mathrm{g}$ was deposited at each test site whereas in tests with $\mathrm{K} 12$ no less than $1250 \mu \mathrm{g}$ of alcohol-precipitable material was deposited at each test site. For K13 this figure was $880 \mu \mathrm{g}$. Despite these wide differences, the levels of reactivity of $\mathrm{K} 12$ and S10 were closely similar and that for K13 was only slightly less. Hence the alcohol-precipitable dry weight of test material cano serve only as a very approximate guide to the activity. of a test suspension which can be assessed onlycs following biological assay in patients with sarcoid=0 osis. Similarly, it is not possible to assess reliably, 을 before validation in man, which sarcoid spleen willos yield a potent test suspension. Thus Siltzbach (1964) reported his evaluation of 38 different tissue sus- 0 pensions, of which only 18 were satisfactory. The remaining 20 were either too weak or elicited non- 0 specific granulomata. Putkonen $(1943 ; 1964)$ stressed $\overrightarrow{\vec{\omega}}$ that the most active Kveim test suspensions wereo frequently obtained from patients whose Kveimg test showed only a weak positive reaction, and it isi of interest that the Kveim test in the donor of spleen ${ }_{\omega}^{-}$ K12 was only weakly positive and that for K13 wasi negative.

The suspension prepared from spleen K13응 appeared to be slightly less reactive than spleen $\mathrm{K} 12$ or S10 as a source of Kveim test material, but the differences are not significant. K13 is a relatively small spleen and is for this reason less suited to 5 yield a continued supply of validated Kveimo material.

This study has in general confirmed the reactivity and selectivity of all the Kveim test suspensions ino patients with active sarcoidosis but has not in-dicated whether these suspensions differ in theiro reactivity. It has also confirmed the greater reactivityo of the Kveim test suspensions in active than in inactive sarcoidosis.

The findings on papule size are of interest in two respects. First, papules were found in 41 of 72 Kveim tests in patients with pulmonary tuberculosis, although none of these tests was positive on biopsy In comparison, only 1 of $36 \mathrm{Kveim}$ tests in healthyo subjects showed a papule at the test site. Secondly, among those with a negative microscopic reading, the mean papule size was greater in patients with active or inactive sarcoidosis than in patients witho tuberculosis or healthy subjects. This suggests that? the papule size provides information supplementaryo to the microscopic reading in the interpretation of the Kveim test result.

Mitchell et al $(1969,1970,1974)$ and Mikhail and Mitchell (1971), using lot 5 of spleen K12, a suspension which in this validation study yielded the expected proportion of positive reactions in patients at different stages of sarcoidosis and a negligible: proportion in those with active or quiescent pul- $-\stackrel{\Phi}{?}$ monary parenchymal tuberculosis or among healthy subjects, found positive reactions in an appreciables proportion of patients with certain other diseases, $\overrightarrow{\mathbb{D}}$ including Crohn's disease (Mitchell et al, 1969? 1970), ulcerative colitis (Mitchell et al, 1974), and tuberculous lymphadenitis (Mikhail and Mitchell, 
1971). Moreover, they encountered a closely similar rate of positive reactions among patients with Crohn's disease after tests with an early batch (0025) of CSL suspension and with another lot (lot 14) derived from spleen K12 (Mitchell et al, 1970). A close concordance of results was also obtained with lot 5 (K12) and with batch 0042 (CSL) in tests among patients with ulcerative colitis (Mitchell et al, 1974), but at a lower rate of reactivity than in patients with Crohn's disease.

Hurley and Bartholomeusz (1968) reported their findings following an evaluation of an early batch of CSL suspension in which biopsy of the Kveim test site was performed if any visible or palpable nodule was detected. If no nodule was visible or palpable the result was read as negative. Positive reactions were encountered in $70 \%$ of 84 patients with histologically proven or clinically definite sarcoidosis and in less than $2 \%$ of 135 patients not suffering from sarcoidosis. Izumi et al (1974) reported their findings following the use of early 002 and 003 (0024-0031) and late 004 (004-2-004-5) batches of CSL Kveim suspension. Of the patients with pulmonary sarcoidosis who were Kveim tested within one year of presentation, $78 \%$ tested with batches 002 and 003 and $88 \%$ tested with batch 004 gave positive reactions. Among patients in whom the chest radiograph showed complete regression of sarcoidosis the difference in Kveim reactivity between the early and late batches was substantial: thus, of those tested with batches 002 and 003 , only $27 \%$ were positive whereas $71 \%$ of those tested with the late batches 004 showed positive reactions. In patients with pulmonary diseases other than sarcoidosis (pulmonary tuberculosis, chronic obstructive lung diseases, silicosis, carcinoma, etc) no positive Kveim tests were encountered in 25 patients tested with the early batches (002 and 003), but of the 153 patients tested with later batches (004) 71 $(53 \%)$ were positive.

More recently, Hurley et al (1975) have reported the results of a study in which biopsy of all Kveim test sites was obligatory and which included patients with a wide variety of diseases other than sarcoidosis: in this study batch $0017-0023$, used in their original validation (Hurley and Bartholomeusz, 1968), and later batches 005-006, which had earlier been shown to give microscopically positive tests among patients with diseases other than sarcoidosis (Izumi et al, 1974), yielded positive tests among patients with sarcoidosis, tuberculosis, Hodgkin's disease, nonHodgkin's lymphoma, Crohn's disease, ulcerative colitis, rheumatoid arthritis, and Weber-Christian disease. It is highly relevant that the early batch 0017-0023 used in the original validation produced the lowest percentage of positive reactions among patients with diseases other than sarcoidosis and that these early batches showed only $12(1.7 \%)$ microscopically positive responses among 722 patient with a wide variety of diseases other than sarcoidosis and Crohn's disease in the continued international Kveim test study (1966-1969) (Hurley and Bartholomeusz, 1971).

The fulfilment of the elaborate design of this present study, which required careful matching of subjects in different clinical categories, turned out to be extremely laborious and time-consuming. The advantages it brought were very slight-marginally more precise assessments of the relative reactivity of the Kveim test in active and inactive sarcoidosis and of its specificity. It contributed nothing to the assessment of any differences in reactivity between the four test suspensions on which the findings of this study are inconclusive. In retrospect it was a mistake to have adopted so demanding a design, and this should also have been clear in prospect.

Differences in reactivity between two test suspensions can be satisfactorily established only by testing substantial numbers of patients with sarcoidosis with the two suspensions in parallel. For this purpose active sarcoidosis cases are to be preferred to inactive cases because of their greater reactivity to Kveim test suspensions, as confirmed by the present study. This approach has been adopted in our subsequent investigations of these and other Kveim test suspensions. With regard to the selectivity of a suspension for sarcoidosis (Mitchell and Scadding, 1974), the difficulties in determining the criteria for an acceptable test suspension become increasingly apparent as additional Kveim tests are made with one particular lot and with sequential lots of test material from a 'validated' tissue source. We conclude that the possibility that positive reactions can be produced selectively in some other diseases following tests with a suspension that gives the expected proportions of reactions in patients with different stages of sarcoidosis and a negligible proportion of these in those with active or quiescent pulmonary tuberculosis must be considered.

We thank Professor J. G. Scadding for his assessment of the Kveim test histology. We are indebted to Miss Brenda Moore for secretarial assistance.

\section{References}

Chase, M. W. (1961). The preparation and standardization of Kveim testing antigen. Amer. Rev. resp. Dis., 84, Nov., pt. 2, 86-88.

Hirsch, J. G., Cohn, Z. A., Morse, S. I., Schaedler, R. W., Siltzbach, L. E., Ellis, J. T., and Chase, M. W. (1961). Evaluation of the Kveim reaction as a diagnostic test for sarcoidosis. New Engl. J. Med., 265, 827-830. 
Hurley, T. H. and Bartholomeusz, C. L. (1968). The Kveim test in sarcoidosis. Med. J. Aust., 2, 947-949.

Hurley, T. H. and Bartholomeusz, C. L. (1971). An international Siltzbach-Kveim test study using an Australian (CSL) test material (1966-1969). In Vth International Conference on Sarcoidosis, Prague, June 16-21, 1969, edited by L. Levinský and F. Macholda, pp. 343-348. Universita Karlova, Prague.

Hurley, T. H., Sullivan, J. R., and Hurley, J. V. (1975). Reaction to Kveim test material in sarcoidosis and other diseases. Lancet, 1, 494-496.

Izumi, T., Kobara, Y., Morioka, S., Sato, A., and Tsuji, S. (1974). False-positive reaction in the Kveim test using the CSL Kveim material. In Proceedings of the VI International Conference on Sarcoidosis, edited by $\mathrm{K}$. Iwai and $\mathrm{Y}$. Hosoda, pp. 77-78. University of Tokyo Press, Tokyo.

James, D. G. and Thompson, A. D. (1955). The Kveim test in sarcoidosis. Quart. J. Med., 24, 49-60.

Mikhail, J. R., and Mitchell, D. N. (1971). Mediastinoscopy: a diagnostic procedure in hilar and paratracheal lymphadenopathy. Postgrad. med. J., 47, 698-704.

Mitchell, D. N., Cannon, P., Dyer, N. H., Hinson, K. F. W., and Willoughby, J. M. T. (1969). The Kveim test in Crohn's disease. Lancet, 2, 571-573.

Mitchell, D. N., Cannon, P., Dyer, N. H., Hinson, K. F. W., and Willoughby, J. M. T. (1970). Further observations on Kveim test in Crohn's disease. Lancet, 2, 496-498.

Mitchell, D. N., Hinson, K. F. W., Dyer, N. H., Willoughby, J. M. T., and Cannon, P. (1974). Some recent observations on the Kveim reaction. In Proceedings of the VI International Conference on Sarcoidosis, edited by K. Iwai and Y. Hosoda, pp. 90-95, University of Tokyo Press, Tokyo.

Mitchell, D. N. and Scadding, J. G. (1974). Sarcoidosis. Amer. Rev. resp. Dis., 110, 774-802.

Nelson, C. T. (1957). The Kveim reaction in sarcoidosis. J. Chron. Dis., 6, 158-177.

Putkonen, T. (1943). Über die Intrakutanreaktion von Kveim (Kvr) bei Lymphogranulomatosis benigna und über das Bild dieser Krankheit im Lichte der Reaktionsergebnisse. Acta Derm.-veneral (Stockh.), 23, Suppl. 10, pp. 191-194.

Putkonen, T. (1964). Source of potent Kveim antigen. Acta med. scand., Suppl., 425, pp. 83-85.
Siltzbach, L. E. (1961a). The Kveim test in sarcoidosis. Amer. med. Ass., 178, 476-482.

Siltzbach, L. E. (1961b). Current status of the Nickerson Kveim reaction. Amer. Rev. resp. Dis., 84, Nov., part $\stackrel{?+}{+}$ 89-93.

Siltzbach, L. E. (1964). Significance and specificity of the Kveim reaction. Acta med. scand., Suppl., 425, pp. 74-7\&0

Siltzbach, L. E. (1967). An international Kveim test study 1960-1966. In La Sarcoidose: Rapports de la IVe Conférenç Internationale, Paris, 12-15 Septembre 1966, sous 18 direction de J. Turiaf et J. Chabot, pp. 201-213. Masson. Paris.

\section{Appendix}

MICROSCOPIC ASSESSMENT OF KVEIM TES BIOPSIES

1 Positive

The essential feature was the presence of one or more granulomas composed principally of epithelioif cells with occasional Langhans type giant cells. The overall appearances closely resembled those seen iक्षे sections from spontaneous sarcoid lesions in man.

2 Equivocal

(a) A diffuse arrangement of epithelioid cells with no true epithelioid cell granulomas.

(b) Focal collections of histiocytes (with lesf abundant cytoplasm and smaller round nucleis with few or no epithelioid cells.

3 Negative

(a) Non-specific inflammatory cells, mononuclea $\mathbb{8}$ cells, lymphocytes, neutrophils, plasma cells eosinophils

(b) Foreign body reaction

(c) Scar with fibroblasts or fibrocytes

(d) Normal tissue 